\title{
A study on the effect of advertisements on customers' willingness to accept banking services based on modulatory role of brand: A case study of Bank Parsian
}

\author{
Abolfazl Danaei $^{\mathrm{a}}$, Ali Jahan ${ }^{\mathrm{b}}$ and Mohammad Saeidfar ${ }^{\mathrm{c}^{*}}$
}

${ }^{a}$ Department of management, Semnan branch, Islamic Azad University, Semnan, Iran

${ }^{b}$ Faculty of engineering, Semnan branch, Islamic Azad university, Semnan, Iran

${ }^{c}$ Department of Industrial management, Semnan branch, Islamic Azad University, Semnan, Iran

\section{H R O N I C L E \\ A B S T R A C T}

Article history:

Received January 5, 2013

Received in revised format

4 April 2013

Accepted 5 April 2013

Available online

April 52013

Keywords:

Advertisement

Brand

Banking industry
During the past few years, there have been growing competition in banking industry in Iran and there is a growing trend on emerge of new banks, which makes it difficult for existing banks to keep market share. In this paper, we study the effect of advertisements on customers' willingness to accept banking services based on modulatory role of brand. The proposed study has been performed among 440 randomly selected customers in city of Tehran, Iran who were doing banking business with one of Iranian banks called Parsian. The results of survey have been analyzed using structural equation modeling and the preliminary results indicate that there was a positive and meaningful relationship between brand advertisement and associate name and brand identification. However, there was no meaningful relationship between brand advertisement and customer loyalty towards to brand. In addition, the results of survey indicate there was a meaningful relationship between brand equity components including perception quality on brand name, customer awareness from brand, loyalty to brand and customers' willingness to accept banking services on modulatory role of brand.

\section{Introduction}

One of the primary concerns in banking industry is to find the effects of building a good brand on attracting more customers (Reichheld \& Sasser, 1990). There is no doubt that advertisement plays an important role on the success of any business units including banks and financial firms and there are literally various studies to learn how to retain existing customers and increase market share through attracting new customers (Reidenbach, 1995; Azad et al., 2013b). For instance, Azad et al. (2013) investigated the impact of new techniques of advertisement in product development by designing a questionnaire for one of Iranian soft drink producers, which consisted of 274 questions in Likert scale and used factor analysis to investigate the results. Azad and Masoumi (2013) detected important

*Corresponding author. Tel: +989368616473

E-mail addresses: Mhd.saeidfar@yahoo.com (M. Saeidfar) 
factors, which are impacting competitive advantage. Banking industry is one of the most competitive industries since in this sector there is not only competition within the firms but also the sector has to compete with financial institutions (Kaynak \& Kucukemiroglu, 1992; Hull, 2002). Most banks provide similar products and services and only better quality product with lower price could be a good tool to distinguish one bank from its competitors. Therefore, taking care of the market share plays an important role on achieving competitive advantages. Various studies have demonstrated that customer retention is up to ten times cheaper than attracting new customers (Heskett et al., 1990; Heshkett et al., 1994). As a result, one may recommend to spend more of a business resources on retaining the existing customers rather than trying to attract new ones. The costs of acquiring customers to replace those who have been lost are high due to the cost of acquiring customers happens only in the beginning stages of the commercial relationship (Reichheld \& Kenny, 1990). Reichheld et al. (2000) investigated the relationship between loyalty and profits.

Customer value is one of the most important factors in the successes of an organization and it is considered as an important source of competitive advantage for any organization (Woodruff, 1997). It is also known as the primary basis for any marketing activity and has been recognized as an important strategic tool to attract and retain customers (Wang \& Lo, 2003; Wang et al., 2004).

Customer satisfaction plays essential role for the success of any business model and Kotler (1997, 1999) defines it as the difference between the level of perceived performance and customer's expectations. Therefore, customer satisfaction is not only the perceived performance of the product achievement, but also it is customer's expectations and a comparison between these two elements will detect customer satisfaction. In other words, when the customer expectations do not fit with his/her perceptions, customer dissatisfaction happens. Fornell (1992) studied on Swedish customers and revealed that although customer satisfaction and quality play important roles for most organizations but there are many industries such as banks, insurance and post where customer satisfaction is more important since it creates more loyalty.

\section{The proposed model}

The proposed study of this paper performs an investigation using a method shown in Fig. 1 as follows,

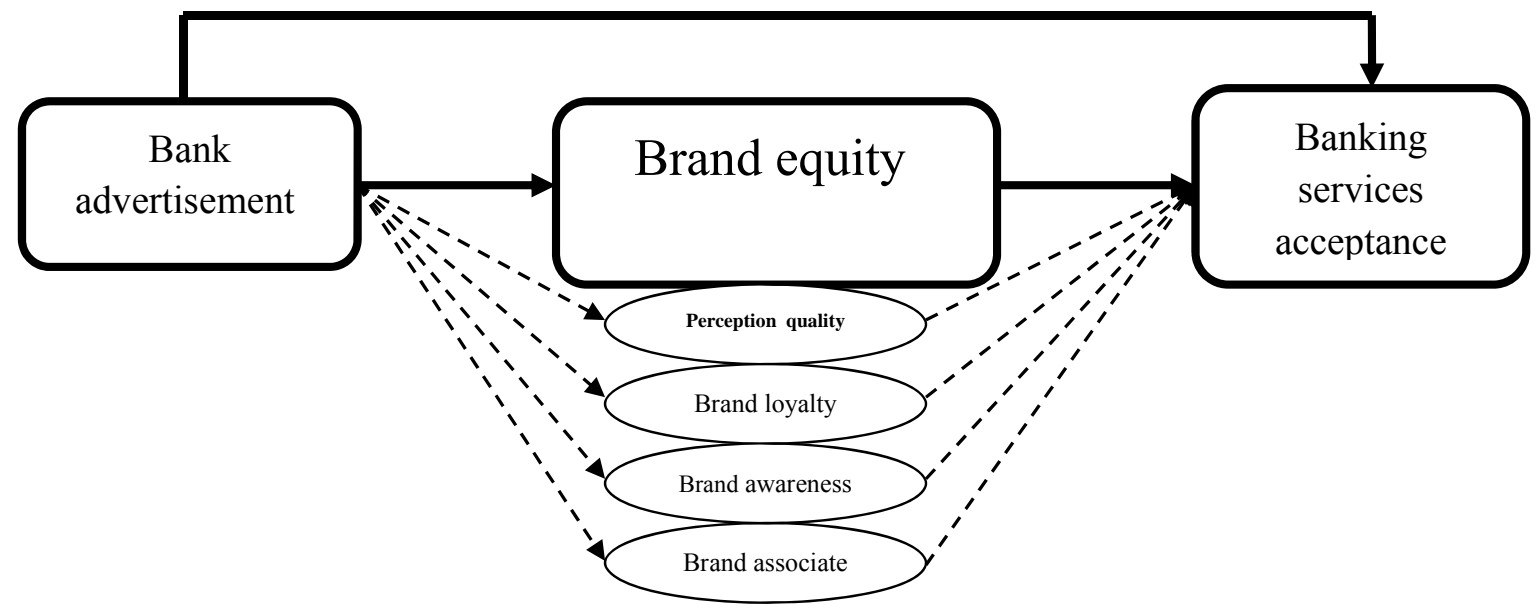

Fig. 1. The proposed framework

As we can observe from Fig. 1, the proposed study investigates the effects of bank advertisement on how customers are encouraged to accept banking services. In other word, the survey looks to find whether advertisement has any meaningful effect on brand equity, whether brand equity influences on customers' willingness to accept banking services and whether advertisement impacts on customers' 
willingness to accept banking services or not. The proposed model of this paper is implemented on one of Iranian banks branches located in Tehran which is the capital city of Iran. The sample size is calculated as follows,

$$
N=Z_{\alpha / 2}^{2} \frac{p \times q}{e^{2}},
$$

where $N$ is the sample size, $p=1-q$ represents the probability, $z_{\alpha / 2}$ is CDF of normal distribution and finally $\varepsilon$ is the error term. For our study we assume $p=0.5, z_{\alpha / 2}=1.96$ and $e=0.05$, the number of sample size is calculated as $N=384$. In this study, we have decided to distribute 440 questionnaires to level up the reliability of the questionnaire. The case study of this survey is associated with Bank Parian, which has 159 different branches distributed in five various regions in city of Tehran, Iran. We have deisgned a questionnaire in Likert scale and distribute 25 questionnaires in each branch and analyzed the result using structural equation modeling based on the implementation of LISREL software package. Table 1 summarizes the results our survey for each question.

\section{Table 1}

The results of

\begin{tabular}{lcccc}
\hline Variable & Question & Factor weight & \% of variance & t-value \\
\hline & 2 & 0.75 & 0.44 & 17.91 \\
Bank advertisement & 8 & 0.81 & 0.34 & 20.16 \\
& 14 & 0.85 & 0.27 & 21.81 \\
\hline Brand awareness & 20 & 0.84 & 0.30 & 21.16 \\
\hline & 4 & 0.84 & 0.30 & 20.93 \\
\hline & 10 & 0.79 & 0.38 & 19.06 \\
\hline Quality perception from brand & 16 & 0.75 & 0.44 & 17.63 \\
\hline & 5 & 0.67 & 0.55 & 15.25 \\
Brand loyalty & 11 & 0.78 & 0.39 & 18.73 \\
& 17 & 0.78 & 0.39 & 18.75 \\
\hline Brand associate & 6 & 0.80 & 0.35 & 19.74 \\
& 12 & 0.78 & 0.38 & 19.09 \\
\hline Willingness to accept bank services & 18 & 0.82 & 0.34 & 20.19 \\
\hline & 7 & 0.75 & 0.44 & 17.82 \\
& 13 & 0.86 & 0.26 & 21.94 \\
\hline
\end{tabular}

As we can observe from the results of Table 1, all t-student values are well greater than 1.96, which means that all components are statistically meaningful. Next, we present the results of the implementation of structural equation modeling based on the proposed framework demonstrated in Fig. 1.

\section{The results}

In this section, we present details of our findings for the proposed study of this survey. 


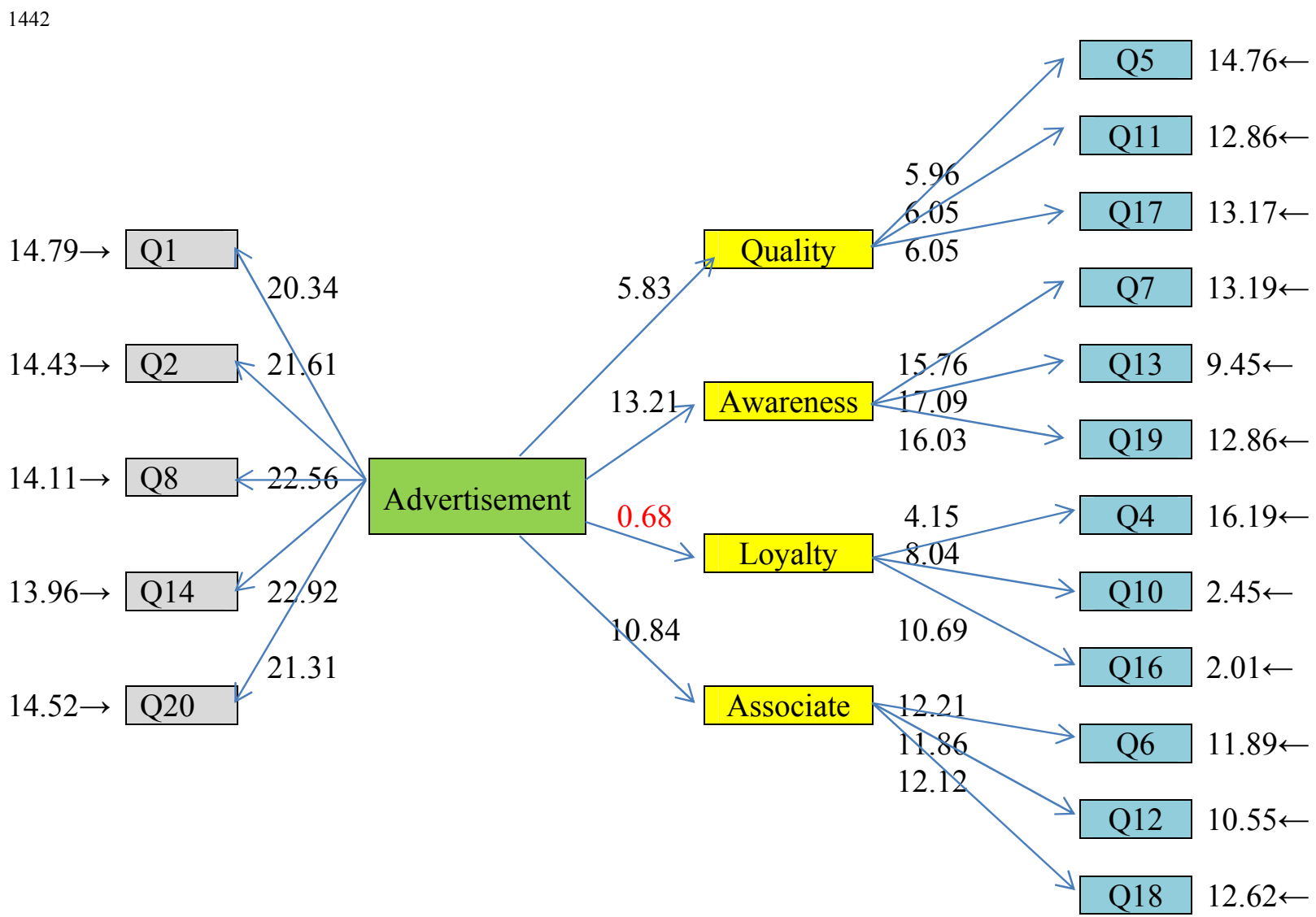

Chi-Square $=1077.22 \mathrm{df}=115 \mathrm{P}-$ Value $=0.0000 \mathrm{RMSEA}=0.067$

Fig. 2. The results of structural equation modeling

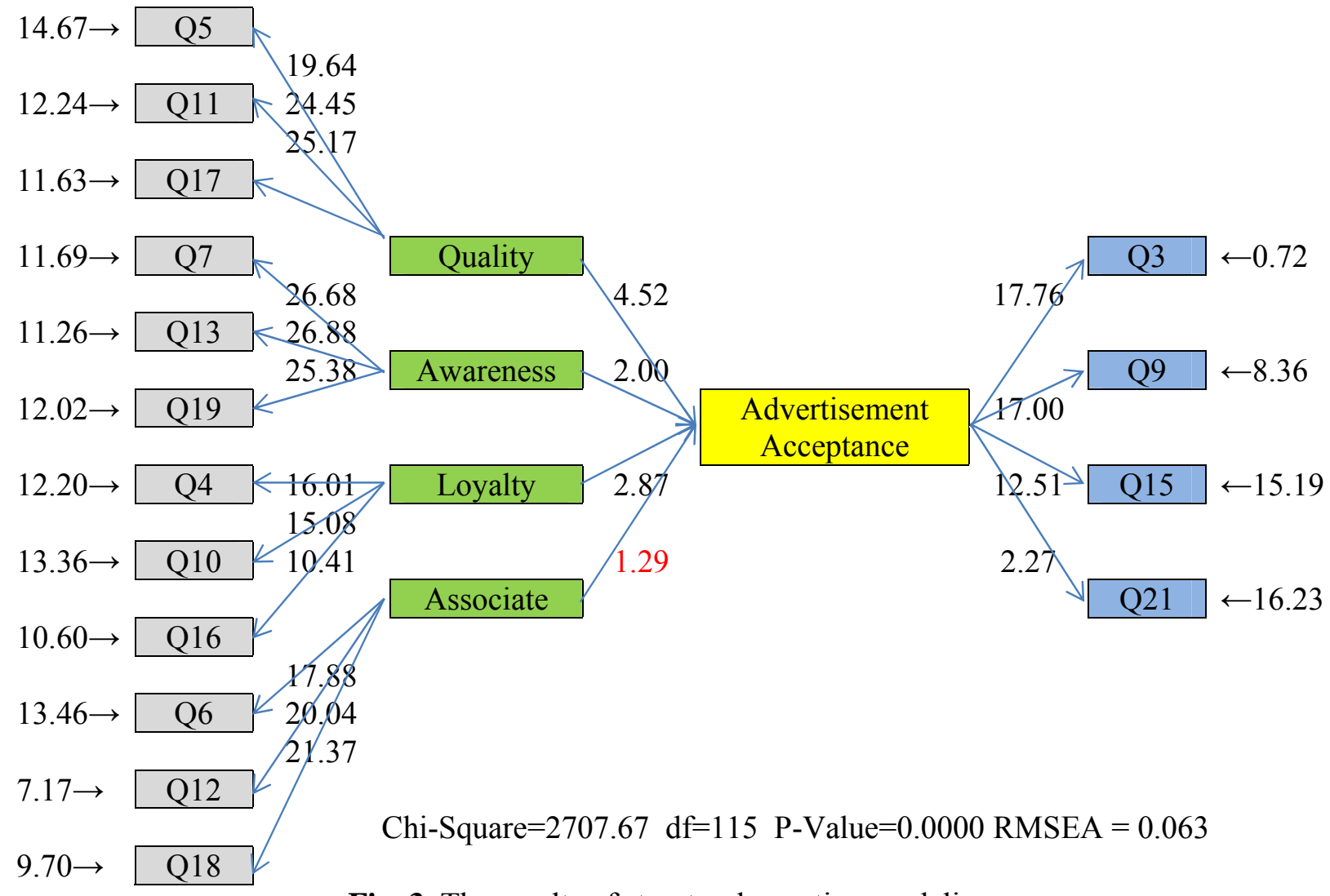

Fig. 3. The results of structural equation modeling 
As we can observe from the results of Fig. 2, the meaningful coefficients between advertisement and quality is 5.83 , between advertisement and awareness is 13.21 , between advertisement and brand associate is equal to 10.84 and they are all meaningful. However, the relationship between advertisement and loyalty is not statistically significant.

Fig. 3 demonstrates the results of the implementation of structural equation modeling. Based on the results, we can see that the relationship between advertisement and quality is equal to 4.52 , between advertisement and awareness is equal to 2.00 , between advertisement and loyalty is equal to 2.87 and they are all statistically significance but the relationship between advertisement and brand associate is equal to 1.29 and it is not statistically significance.

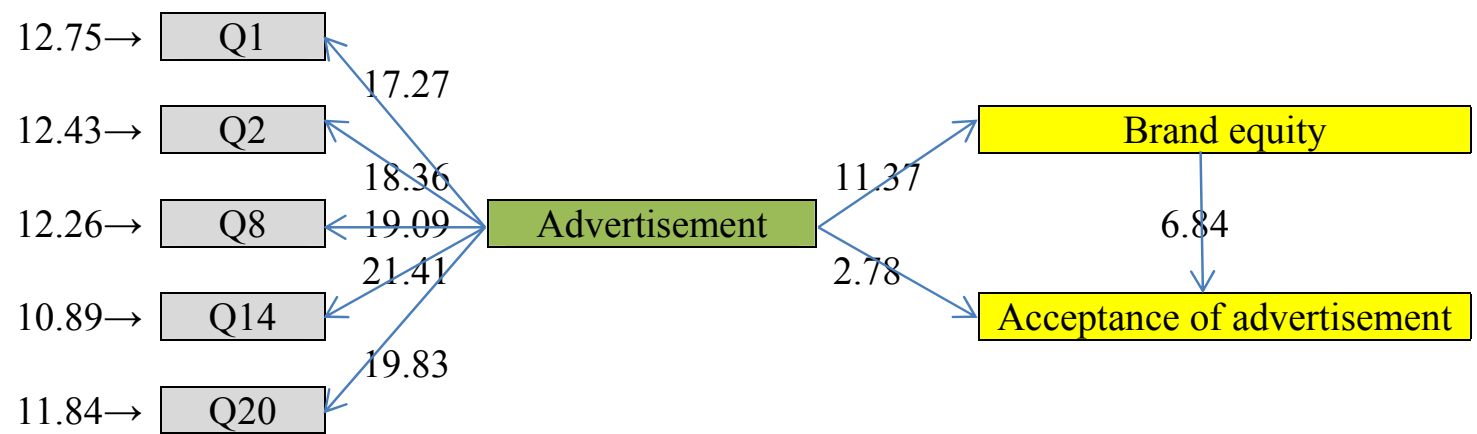

Fig. 4. The results of the proposed model

Based on the results of Fig. 4, we can conclude that advertisement influences brand equity and increases the rate of acceptance of advertisement, positively. In addition, brand equity substantially influences acceptance of advertisement.

\section{Summary and conclusion}

In this paper, we have performed an empirical investigation to find out the relationship between different components of brand equity and accepting advertisement. We have built a conceptual framework and examined various hypotheses using structural equation modeling in one of Iranian banks located in city of Tehran, Iran. Table 2 summarizes the results of our survey.

Table 2

The summary of the testing various hypotheses

\begin{tabular}{lll}
\hline Path & t-value & Result \\
\hline Bank advertisement $\rightarrow$ Quality perception of brand & 5.83 & Confirmed \\
Bank advertisement $\rightarrow$ Brand awareness & 13.21 & Confirmed \\
Brand awareness $\rightarrow$ Brand advertisement & 0.68 & Rejected \\
Brand Loyalty $\rightarrow$ Brand associate & 10.84 & Confirmed \\
Quality perception of brand $\rightarrow$ Acceptance of advertisement & 4.52 & Confirmed \\
Brand awareness $\rightarrow$ Acceptance of advertisement & 2.00 & Confirmed \\
Brand Loyalty $\rightarrow$ Acceptance of advertisement & 2.87 & Confirmed \\
Brand associate $\rightarrow$ Acceptance of advertisement & 1.29 & Rejected \\
\hline
\end{tabular}

Based on the results of Table 2, brand advertisement influences quality perception of brand as well as brand awareness but brand awareness does not influence advertisement. In addition, brand loyalty impacts brand associate and acceptance of advertisement but brand associate does not impact acceptance of advertisement. 


\section{References}

Azad, N., \& Masoumi, M. (2012). The impact of packaging on product competition. Management Science Letters, 2(8), 2789-2794.

Azad, N., Zarifi, S.F., Hozori, S., \& Hashemi, S. (2013a). A survey on critical factors influencing new advertisement methods. Management Science Letters, 3(2), 569-574.

Azad, N. Zarifi, S.F., \& Hozouri, S. (2013b). A factor analysis to find critical success factors in retail brand. Management Science Letters, 3(2), 827-332.

Fornell, C. (1992). A National Customer Satisfaction Barometer: The Swedish Experience. Journal of Marketing, 56(1), 6-21.

Heskett, J. L., Sasser, W. E. \& Hart, C. W. (1990). Service Breakthroughs - Changing the Rules of the Game, The Free Press, NewYork, NY.

Heskett, J.L., Jones, T.O., Loveman, G.W., Sasser, W.E., Jr., \& Schlesinger, L.A. (1994). Putting the service-profit chain to work. Harvard Business Review, 72(2), 164-170.

Hull, L. (2002). Foreign-owned Banks: Implications for New Zealand's Financial Stability. Discussion Paper Series, DP2002/05.

Kaynak, E., \& Kucukemiroglu, O. (1992). Bank and Product Selection: Hong Kong. The International Journal of Bank Marketing, 10(1), 3-17.

Kotler, P. (1997). Marketing Management: Analysis, Planning,Implementation, and Control, 9th ed., Prentice-Hall, Upper Saddle River, NJ.

Kotler, P. (1999). Marketing Management-An Asian Perspective. Singapore: Prentice Hall, Inc., 2530.

Reidenbach, R.E. (1995). Value-Driven Bank: Strategies for Total Market Satisfaction. Irwin Professional, U.K.

Reichheld, F. F \& Kenny, D. (1990). The hidden advantages of customer retention. Journal of Retail Banking, 7(4), 19-23.

Reichheld, F. F. \& Sasser, W.E. Jr (1990). Zero defections: quality comes to services. Harvard Business Review, 68, 105-111.

Reichheld, F.F., Markey, R.G. Jr. \& Hopton, C. (2000). The loyalty effect-the relationship between loyalty and profits. European Business Journal, 12(3), 134-9.

Woodruff, R. B. (1997). Customer value: the next source of competitive advantage. Journal of the Academy of Marketing Science, 25(2), 139-53.

Wang, Y. G. \& Lo, H. P. (2003). Service quality, customer satisfaction, customer value and behavior intentions: evidence from China's telecommunication industry. The Journal of Policy, Regulation and Strategy for Telecommunications, 4(6), 50-60.

Wang, Y. G., Lo, H. P., Chi, R. Y. \& Yang, Y. H. (2004). An integrated framework for customer value and customer relationship management performance: A customer-based perspective from China. Managing Service Quality, 14 (2/3), 169-182. 